\title{
Pengaruh Persepsi Mengenai Profesi Akuntan Publik, Motivasi, dan Kecerdasan Adversity Terhadap Minat Menjadi Akuntan Publik
}

\author{
Putu Vicky Yuliana Paramita $S^{1}$ \\ Maria Mediatrix Ratna Sari² \\ ${ }^{1,2}$ Fakultas Ekonomi dan Bisnis Universitas Udayana (Unud), Bali, Indonesia \\ e-mail: vickyyulianaparamita@gmail.com
}

\begin{abstract}
ABSTRAK
Akuntan publik berperan dalam peningkatan kualitas dan kredibilitas informasi keuangan. Minat masyarakat untuk menjadi seorang akuntan publik masih rendah. Penelitian ini bertujuan untuk mengetahui minat mahasiswa akuntansi non reguler menjadi akuntan publik yang diukur dari persepsi mahasiswa, motivasi diri, serta kecerdasan adversity. Penelitian ini dilakukan pada mahasiswa akuntansi non reguler angkatan 2015 di Fakultas Ekonomi dan Bisnis Universitas Udayana. Penentuan sampel menggunakan metode non probability sampling dengan teknik sampling jenuh. Jumlah responden yang digunakan dalam penelitian ini adalah sebanyak 158 orang. Metode pengumpulan data dilakukan metode survey dengan teknik kuesioner yang diukur menggunakan skala likert. Hasil penelitian ini menunjukkan bahwa variabel persepsi mahasiswa, motivasi diri, dan kecerdasan adversity memiliki pengaruh yang positif terhadap minat mahasiswa akuntansi non reguler Universitas Udayana menjadi akuntan publik.
\end{abstract}

Kata kunci: persepsi mahasiswa, motivasi diri, kecerdasan adversity, minat menjadi akuntan publik.

\begin{abstract}
Public accountants play a role in improving the quality and credibility of financial information. The interest of the people to become a public accountant, is still low. This study aims to determine the interest of non-regular accounting students to become public accountants as measured by student perceptions, self-motivation, and adversity intelligence. This research was conducted on 2015 non-regular accounting students at the Faculty of Economics and Business at Udayana University. Determination of samples using non-probability sampling method with saturated sampling technique. The number of respondents used in this study was 158 people. Data collection method is carried out by a survey method with questionnaire techniques that are measured using a Likert scale. The results of this study indicate that the variables of student perception, self motivation, and adversity intelligence have a positive influence on the interest of non-regular accounting students at Udayana University to become public accountants.
\end{abstract}

Keywords: student perception, self motivation, adversity intelligence, interest in becoming a public accountant.

\section{PENDAHULUAN}

Globalisasi seperti saat ini, semua negara dituntut untuk lebih berkembang. Termasuk juga Indonesia sebagai salah satu negara yang selalu nmengikuti 
perkembangan zaman. Tentu saja hal tersebut berpengaruh dalam penyajian laporan keuangan. Dengan adanya kemajuan zaman seperti sekarang ini sudah pasti dituntut untuk meningkatkan akuntabilitas dan transparansi dalam setiap penyajian laporan keuangan dan hal ini merupakan bagian dari tanggungjawab akuntan publik. Akuntan publik dapat dikatakan elemen penting untuk mewujudkan kehidupan masyarakat yang transparan, akuntabel, dan perekonomian yang bebas dari kecurangan serta penipuan yang bersifat kecurangan.

Praktik akuntansi di Indonesia sejatinya sudah ada sejak zaman kolonial. Dimana pada masa itu, profesi akuntan dipegang oleh akuntan Belanda dan beberapa akuntan Indonesia. Pendidikan tata buku juga diajarkan di sekolahsekolah formal pada tingkat Sekolah Menengah. Namun profesi akuntan publik sendiri mulai berkembang pada tahun sekitar 1967, 1968 yaitu pada saat pemerintahan mulai mengeluarkan undang-undang tentang penanaman modal asing. Sejak saat itu profesi akuntan publik terus mengalami perkembangan hingga saaat ini.

Secara umum, setelah melalui pendidikan S1, sarjana akuntansi mempunyai berbagai alternatif pilihan. Baik melanjutkan untuk mengikuti pendidikan profesi akuntansi atau melanjutkan ke jenjang akademik S2 maupun langsung berkecimpung dalam dunia kerja. Dalam dunia kerja sendiri, terdapat berbagai alternatif profesi yang dapat dijalankan oleh sarjana akuntansi, misalnya sebagai akuntan publik, akuntan pendidik, akuntan pemerintah atau akuntan perusahaan. 
Profesi akuntan publik bertanggungjawab untuk menaikkan tingkat keandalan laporan keuangan perusahaan, sehingga masyarakat memperoleh informasi keuangan yang handal sebagai dasar pengambilan keputusan. Guna menunjang profesionalismenya sebagai akuntan publik maka auditor dalam melaksanakan tugas auditnya harus berpedoman pada standar audit yang ditetapkan oleh Ikatan Akuntan Indonesia (IAI). Akuntan publik berperan dalam peningkatan kualitas dan kredibilitas informasi keuangan, serta mendorong peningkatan good corporate governance.

Tabel 1.

Jumlah Akuntan Profesional Negara ASEAN yang Terdaftar dan Jumlah Penduduk tahun 2015

\begin{tabular}{cccc}
\hline No & Negara & $\begin{array}{c}\text { Jumlah Akuntan Profesional per } \\
\text { Januari 2015 }\end{array}$ & $\begin{array}{c}\text { Jumlah Penduduk dalam } \\
\text { ribuan }\end{array}$ \\
\hline 1 & Brunei & 56 & 406,2 \\
2 & Kamboja & 291 & $14.962,6$ \\
3 & Indonesia & 24.587 & $248.818,1$ \\
4 & Laos & 176 & $6.644,0$ \\
5 & Malaysia & 31.185 & $29.948,0$ \\
6 & Myanmar & 1.948 & $61.568,0$ \\
7 & Filipina & 18.214 & $99.384,5$ \\
8 & Singapura & 28.891 & $5.399,2$ \\
9 & Thailand & 62.739 & $68.251,0$ \\
10 & Vietnam & 9.800 & $89.708,9$ \\
& Total & 178.517 & $625.090,5$ \\
\hline Sumber & IAI 2015 & &
\end{tabular}

Pertumbuhan jumlah akuntan publik di Indonesia jika ditinjau dari segi kuantitas bisa dikatakan tergolong rendah apabila dibandingkan dengan NegaraNegara lainnya di ASEAN. Perkembangan jumlah akuntan profesional di NegaraNegara ASEAN dapat dilihat pada Tabel 1. 
Berdasarkan tabel diatas dapat dilihat bahwa perkembangan jumlah profesi akuntan di Indonesia relatif masih rendah karena jumlah akuntan profesional di Negara Indonesia menduduki peringkat keempat terbanyak setelah Negara Thailand, Malaysia, dan Singapura. Hal ini sangat disayangkan mengingat jumlah penduduk di Indonesia merupakan yang terbesar yaitu mencapai kurang lebih 249 juta penduduk namun hanya memiliki akuntan profesional yang terdaftar sejumlah 24.587 orang. Apabila dibandingkan dengan Negara Thailand, Malaysia, dan Singapura, Negara Indonesia seharusnya memiliki potensi yang lebih besar dalam meningkatkan jumlah akuntan profesional karena didukung oleh banyaknya jumlah penduduk. Hal tersebut menunjukkan bahwa minat masyarakat Indonesia khususnya lulusan akuntansi untuk menjadi seorang akuntan publik masih rendah. Rendahnya perkembangan jumlah akuntan publik di Indonesia dapat disebabkan oleh berbagai faktor yang mempengaruhi minat seorang lulusan akuntansi untuk tidak menjadikan profesi akuntan publik dalam pilihan karirnya. Motivasi merupakan suatu dorongan yang akan timbul dari dalam diri seseorang untuk dapat mencapai semua rencana maupun keinginan yang dikehendakinya.

Landasan teori yang mendasari penelitian ini adalah teori motivasi. Saat ini banyak teori motivasi yang berkembang, namun yang banyak dianut sampai sekarang adalah teori kebutuhan (Hadiprasetyo dan Sagoro, 2014). Dasar dari teori ini menyatakan bahwa segala tindakan yang dilakukan oleh manusia pada hakikatnya adalah untuk memenuhi segala kebutuhannya.

Minimnya minat para mahasiswa untuk menjadi akuntan publik karena profesi akuntan publik kurang diminati kalangan muda dan fresh graduate 
(sarjana baru). Faktor yang mempengaruhi sedikitnya minat lulusan mahasiswa akuntansi untuk menjadi akuntan publik yaitu anggapan risiko akuntan publik yang ditanggung sangat besar sedangkan penghasilannya tidak sesuai dengan beban risiko yang ditanggung oleh akuntan publik. Risiko yang dimaksud adalah akuntan publik harus mampu menjaga independensi dalam mengaudit laporan keuangan perusahaan yang diaudit (Fitria, 2016)

Banyaknya persyaratan yang harus ditempuh bagi para mahasiswa sebelum ataupun sesudah menjadi akuntan publik juga menjadi penyebab kurangnya minat untuk menjadi akuntan publik. Namun akhir-akhir ini pemerintah berupaya untuk mengurangi persyaratan-persyaratan yang sekiranya memberatkan agar banyak lulusan mahasiswa nanti dapat memilih karir menjadi akuntan publik. Diantaranya yaitu diadakan ujian langsung sertifikasi untuk menjadi akuntan publik, sehingga pada mahasiswa akuntansi yang sudah lulus sarjana dapat langsung mengikuti ujian tersebut tanpa harus mengiktui pendidikan profesi akuntansi. Namun tentu saja persiapan yang dibutuhkan harus lebih ekstra dibanding yang sudah mengikuti pendidikan profesi akuntansi. (Arifianto, 2014)

Persepsi seseorang akan suatu hal dapat mempengaruhi pemikiran orang tersebut. Dalam hal ini persepsi mahasiswa akuntansi mengenai profesi akuntan publik. Carol Wade dan Carol Travis (2007:194) berpendapat bahwa persepsi merupakan proses pengaturan dan penerjemahan informasi sensorik oleh otak. Persepsi dapat dikatakan merupakan salah satu aspek psikologis yang penting bagi manusia dalam merespon kehadiran berbagai aspek dan gejala sekitarnya. Persepsi mengandung pengertian yang sangat luas, menyangkut intern dan 
ekstern. Apabila seseorang mempunyai persepsi yang positif akan sesuatu hal maka cenderung akan mendukung hal tersebut. Begitu pula sebaliknya apabila seseorang mempunyai persepsi yang negatif akan sesuatu hal maka cenderung untuk menghindari hal tersebut.

Menurut Sardiman (2005) motivasi diri adalah suatu motif-motif (daya penggerak) yang menjadi aktif dan berfungsinya tidak perlu dirangsang dari luar karena dari diri individu sudah terdapat dorongan untuk melakukan sesuatu. Motivasi diri juga juga dapat disebut motivasi internal. Dalam kehidupan seharihari motivasi diri dibutuhkan karena dapat menyemangati diri seseorang untuk mencapai apa yang diinginkannya. Seseorang yang mempunyai motivasi diri yang kuat akan sesuatu hal pasti cenderung akan berusaha semaksimal mungkin untuk mendapatkan hal tersebut. Sehingga ia akan melakukan apapun untuk mencapai hal yang diinginkannya. Motivasi diri dapat digambarkan dengan kemauan untuk maju, kemampuan dalam mengambil inisiatif dan bersikap efektif, serta kemampuan dalam menghadapi kegagalan. Mahasiswa akuntansi yang memiliki motivasi diri yang kuat untuk menjadi seorang akuntan publik, pasti akan selalu berusaha sebaik mungkin agar dapat mencapai keinginannya tersebut.

Kecerdasan adversity adalah suatu konsep mengenai kualitas pribadi yang dimiliki seseorang untuk menghadapi berbagai kesulitan dan dalam usaha mencapai kesuksesan di berbagai bidang dalam hidupnya (Paul G Stolz, 2000: 9). Adversity Intelligence menginformasikan pada individu mengenai kemampuannya dalam menghadapi sebuah keadaan atau situasi yang sulit dan kemampuan untuk mengatasinya, meramalkan individu yang mampu dan tidak mampu menghadapi 
kesulitan, meramalkan mereka yang akan melampaui dan mereka yang akan gagal melampauin harapan-harapan atas kinerja dan potensi yang dimiliki, dan meramalkan individu yang akan menyerah dan yang akan bertahan dalam menghadapi kesulitan. dengan kata lain, kecerdasan adversity mempengaruhi minat mahasiswa secara positif. Mahasiswa yang memiliki kecerdasan adversity yang tinggi, maka ia akan memiliki semangat yang tinggi serta mampu menghadapi setiap kesulitan dan tantangan yang muncul dalam persyaratan untuk menjadi seorang akuntan publik.

Menurut (Dewi, 2018) minat merupakan salah satu aspek psikis manusia yang dapat mendorong untuk mencapai tujuan. Seseorang yang memiliki minat terhadap suatu objek, cenderung untuk memberikan perhatian atau merasa senang yang lebih besar kepada objek tersebut. Namun apabila objek tersebut tidak menimbulkan rasa senang, maka seseorang itu tidak akan memiliki minat pada objek tersebut. Minat memiliki pengaruh yang cukup kuat dalam pencapaian prestasi pada suatu pekerjaan, jabatan atau karir. Suatu pekerjaan tentunya tidak dapat terselesaikan dengan baik apabila seseorang tidak memiliki minat untuk menyelesaikan pekerjaan tersebut (Dewi, 2018).

Penelitian yang dilakukan oleh Arifianto (2014) yang meneliti tentang Pengaruh Motivasi Diri Dan Persepsi Mengenai Profesi Akuntan Publik Terhadap Minat Menjadi Akuntan Publik Pada Mahasiswa Prodi Akuntansi Fakultas Ekonomi Universitas Negeri Yogyakarta. Persamaan penelitian ini dengan penelitian relevan adalah sama sama menggunakan motivasi diri dan persepsi mengenai profesi akuntan publik sebagai variabel independennya dan minat 
mahasiswa menjadi akuntan publik sebagai variabel dependennya. Perbedaan dengan penelitian relevan adalah dalam penelitian ini menambahkan kecerdasan adversitas sebagai variabel independennya dan perbedaannya juga terdapat dalam lokasi penelitian. Lokasi penelitian yang dipilih dalam penelitian ini adalah Fakultas Ekonomi Dan Bisnis Universitas Udayana. Hasil dari penelitiannya adalah motivasi diri dan persepsi mengenai profesi akuntan publik berpengaruh positif dan signifikan terhadap minat menjadi akuntan publik.

Hasil penelitian Fitria (2016) menunjukkan bahwa persepsi dan minat mahasiswa jurusan akuntansi fakultas ekonomi terhadap profesi akuntan berpengaruh secara positif dan signifikan terhadap profesi akuntan publik. Dalam penelitian sebelumnya yang dilakukan Rachman (2012) menjelaskan bahwa motivasi berpengaruh terhadap minat mahasiswa akuntansi untuk berprofesi sebagai akuntan publik. Berdasarkan hasil wawancara yang dilakukan oleh peneliti pada sebagian mahasiswa, apabila diberikan pertanyaan mengenai minat menjadi akuntan publik, mereka masih menyatakan enggan untuk mengambil profesi tersebut.

Robbins dan Judge (2009:173) mendefinisikan persepsi sebagai suatu proses yang ditempuh individu untuk mengorganisasikan dan menfsirkan kesan -kesan indera mereka agar memberi makna bagi lingkungan mereka. Persepsi seseorang tidak timbul begitu saja, tetapi ada berbagai macam faktor yang mempengaruhinya. Faktor itulah yang menyebabkan mengapa dua orang yang melihat sesuatu mungkin memberi interpretasi yang berbeda tentang yang dilihatnya tersebut. Teori motivasi yang diungkapkan oleh Robbins (2011) 
menyatakan bahwa sikap seseorang terbentuk dari tiga komponen salah satunya cognitive component yaitu merupakan keyakinan dari informasi yang dimiliki oleh seseorang yang akan mempengaruhi minat seseorang terhadap terhadap profesi yang akan dijalani. Apabila seseorang mempunyai persepsi yang positif akan sesuatu hal, maka cenderung akan mendukung hal tersebut . Begitu pula sebaliknya apabila seseorang mempunyai persepsi yang negatif akan sesuatu hal maka cenderung untuk menghindari hal tersebut. Setiap individu dalam mempersepsikan mengenai profesi akuntan publik bermacam-macam. Ada yang mempersepsikan mengenai akuntan publik itu positif maupun negatif sehingga secara tidak langsung dapat mempengaruhi keinginannya untuk berprofesi sebagai akuntan publik.

Pada penelitian sebelumnya yang dilakukan oleh Diana (2015) menyatakan bahwa persepsi berpengaruh terhadap pemilihan karir sebagai akuntan publik oleh mahasiswa akuntansi. Dimana mahasiswa selama belajar di perguruan tinggi menerima informasi yang berhubungan dengan akuntan baik secara formal maupun informal. Informasi tersebut dapat memberikan persepsi yang berbeda dari kenyataan yang obyektif. Cara individu dalam pengambilan dan kualitas dari pilihan terakhir mereka sebagian besar dipengaruhi oleh persepsi mereka (Robbis dan Judge, 2009:173). Dalam hal ini, Mahasiswa akuntansi akan memilih profesi tertentu karena dia mempunyai persepsi yang baik terhafap profesi tersebut. Berdasarkan uraian tersebut, maka dapat disimpulkan hipotesis sebagai berikut:

$\mathrm{H}_{1}$ : Semakin tinggi persepsi mahasiswa mengenai profesi akuntan publik maka semakin tinggi minat mahasiswa akuntansi menjadi akuntan publik. 
Menurut Sardiman (2005), motivasi diri adalah suatu motif-motif (daya penggerak) yang menjadi aktif dan berfungsinya tidak perlu dirangsang dari luar karena dari diri individu sudah terdapat dorongan untuk melakukan sesuatu. Motivasi diri juga juga dapat disebut motivasi internal. Dalam kehidupan seharihari motivasi diri dibutuhkan karena dapat menyemangati diri seseorang untuk mencapai apa yang diinginkannya. Seseorang yang mempunyai motivasi diri yang kuat akan sesuatu hal pasti cenderung akan berusaha semaksimal mungkin untuk mendapatkan hal tersebut. Sehingga ia akan melakukan apapun untuk mencapai hal yang diinginkannya. Motivasi diri dapat digambarkan dengan kemauan untuk maju, kemampuan dalam mengambil inisiatif dan bersikap efektif, serta kemampuan dalam menghadapi kegagalan. Mahasiswa akuntansi yang memiliki motivasi diri yang kuat untuk menjadi akuntan publik, pasti akan selalu berusaha sebaik mungkin agar dapat mencapai keinginannya tersebut.

Motivasi diri dapat digambarkan dengan suatu kemauan untuk maju, bertindak efektif, serta kemampuan dalam menghadapi suatu kegagalan yang dialami. Mahasiswa akuntansi yang mempunyai motivasi yang kuat untuk menjadi akuntan publik pasti akan selalu berusaha sebaik mungkin agar dapat mencapai keinginannya tersebut. Penelitian sebelumnya yang dilakukan Arifianto (2014) menyatakan bahwa motivasi diri berpengaruh positif terhadap minat menjadi akuntan publik pada mahasiswa prodi akuntansi fakultas ekonomi universitas negeri yogyakarta. Berdasarkan uraian diatas, maka hipotesis kedua yang diajukan adalah sebagai berikut:

$\mathrm{H}_{2}$ : Semakin tinggi motivasi diri mahasiswa maka semakin tinggi minat mahasiswa akuntansi menjadi akuntan publik. 
Kecerdasan Adversity juga mempengaruhi minat mahasiswa untuk menjadi akuntan publik. (Adversity Intelligence) adalah suatu konsep mengenai kualitas pribadi yang dimiliki seseorang untuk menghadapi berbagai kesulitan dan dalam usaha mencapai kesuksesan di berbagai bidang dalam hidupnya (Paul G Stolz, 2000: 9). Adversity Intelligence menginformasikan pada individu mengenai kemampuannya dalam menghadapi sebuah keadaan atau situasi yang sulit dan kemampuan untuk mengatasinya, meramalkan individu yang mampu dan tidak mampu menghadapi kesulitan, meramalkan mereka yang akan melampaui dan mereka yang akan gagal melampauin harapan-harapan atas kinerja dan potensi yang dimiliki, dan meramalkan individu yang akan menyerah dan yang akan bertahan dalam menghadapi kesulitan. dengan kata lain, kecerdasan adversity mempengaruhi minat mahasiswa secara positif. Mahasiswa yang memiliki kecerdasan adversity yang tinggi, maka ia akan memiliki semangat yang tinggi serta mampu menghadapi setiap kesulitan dan tantangan yang muncul dalam persyaratan untuk menjadi seorang akuntan publik. Berdasarkan uraian diatas, maka hipotesis ketiga yang diajukan adalah sebagai berikut:

$\mathrm{H}_{3}$ : Semakin tinggi kecerdasan adversity mahasiswa maka semakin tinggi minat mahasiswa akuntansi menjadi akuntan publik.

\section{METODE PENELITIAN}

Penelitian ini menggunakan pendekatan pendekatan kuantitatif yang berbentuk asosiatif. Metode penelitian kuantiatif dapat diartikan sebagai metode penelitian yang berlandaskan positivisme dimana data penelitian berupa angka-angka dan analisis menggunakan statistik (Sugiyono, 2017). Penelitian berbentuk asosiatif 
merupakan penelitian yang bertujuan untuk mengetahui hubungan antara dua variabel atau lebih. Kerangka konseptual akan dijelaskan dalam Gambar 1.

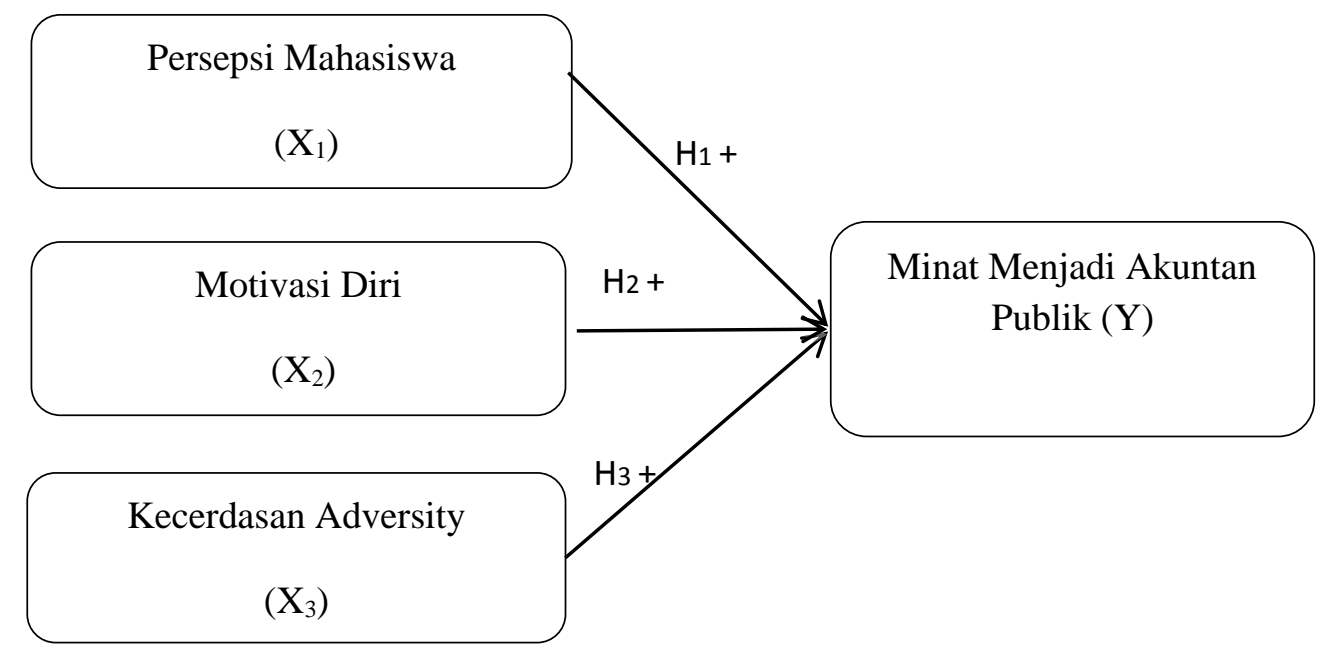

Sumber : Data diolah, 2018

\section{Gambar 1. Kerangka Konseptual Penelitian}

Lokasi penelitian dilakukan di Fakultas Ekonomi dan Bisnis Program S1 Non Reguler Universitas Udayana yang beralamat di Jalan P.B. Sudirman Denpasar. Alasan yang mendasari dipilihnya lokasi ini karena penelitian ini merupakan studi empiris pada mahasiswa jurusan akuntansi non reguler angkatan 2015 yang segala aktivitasnya dilaksanakan di Kampus Sudirman, Fakultas Ekonomi dan Bisnis Universitas Udayana. Sedangkan obyek dalam penelitian ini adalah minat mahasiswa jurusan akuntansi Fakultas Ekonomi dan Bisnis Program Non Reguler Universitas Udayana menjadi Akuntan Publik yang dipengaruhi oleh persepsi mahasiswa, motivasi diri dan kecerdasan adversity.

Variabel bebas dalam penelitian ini adalah persepsi mahasiswa $\left(\mathrm{X}_{1}\right)$, motivasi diri $\left(\mathrm{X}_{2}\right)$ dan kecerdasan adversity $\left(\mathrm{X}_{3}\right)$. Sedangkan variabel terikat dalam penelitian ini adalah minat menjadi akuntan publik (Y). skala pengukuran yang digunakan dalam penelitian ini menggunakan metode skala Likert. Skala 
Likert menggunakan empat skor dengan penilaian Skor empat untuk jawaban sangat setuju dengan kode SS, Skor tiga untuk jawaban setuju dengan kode S, Skor dua untuk jawaban tidak setuju dengan kode TS, dan Skor satu untuk jawaban sangat tidak setuju dengan kode STS.

Jenis data yang digunakan dalam penelitian ini adalah data kualitatif berupa nama-nama mahasiswa akuntansi program S1 non regular angkatan 2015, indikator-indikator yang terdapat dalam kuesioner. Data kuantitatif yang digunakan dalam penelitian ini berupa skor atau jawaban dari pernyataanpernyataan yang terdapat dalam kuesioner. Sedangkan sumber data yang digunakan dalam penelitian ini adalah data primer yang diperoleh dari jawaban kuesioner yang telah disebar kepada seluruh mahasiswa akuntansi non reguler angkatan 2015 di Fakultas Ekonomi dan Bisnis Universitas Udayana.

Populasi dalam penelitian ini adalah seluruh mahasiswa jurusan akuntansi semester 6 angkatan 2015 yang berjumlah 158 orang. Alasan peneliti memilih mahasiswa akuntansi pada tingkatan tersebut karena mahasiswa pada semester 6 telah memiliki rencana atau pemikiran alternatif mengenai apa yang akan mereka lakukan setelah kelulusannya serta mereka telah memiliki bayangan untuk memilih karir yang mereka inginkan. Populasi mahasiswa akuntansi angkatan 2015 dijelaskan dalam Tabel 2. 
Tabel 2.

Jumlah Mahasiswa Aktif Akuntansi Non Reguler Angkatan 2015 Fakultas Ekonomi dan Bisnis Universitas Udayana

\begin{tabular}{lc}
\hline Jumlah Mahasiswa & 184 \\
\hline Non Aktif & 8 \\
Lulus & 18 \\
Cuti & 0 \\
\hline Total Mahasiswa Aktif & 158 \\
\hline Sumber: Data diolah, 2018 &
\end{tabular}

Sampel dalam penelitian ini adalah keseluruhan jumlah populasi. Metode penentuan sampel yang dipilih non probability sampling dengan teknik sampling jenuh. Sampling jenuh adalah teknik penentuan sampel bila semua anggota populasi digunakan sebagai sampel. (Sugiyono,2017:85). Metode pengumpulan data yang digunakan dalam penelitian ini adalah metode survey dengan teknik kuesioner yang disebarkan secara langsung kepada mahasiswa akuntansi Program Non Reguler Fakultas Ekonomi dan Bisnis Universitas Udayana.

Teknik analisis data yang digunakan dalam penelitian ini adalah teknik analisis regresi linier berganda, Sebelum melakukan pengujian regresi, terdapat beberapa asumsi yang harus dipenuhi agar data yang akan dimasukkan dalam model regresi telah memenuhi ketentuan dan syarat dalam regresi. Uji asumsi klasik dalam penelitian ini mencakup uji normalitas, multikolinearitas, dan heteroskedastisitas. Model regresi linier berganda dirumuskan sebagai berikut.

$\mathrm{Y}=\alpha+\beta_{1} \mathrm{X}_{1+} \beta_{2} \mathrm{X}_{2}+\mathrm{e}=$

Keterangan:

Y : Minat Menjadi Akuntan Publik

$\alpha \quad$ : Konstanta

$\beta_{1}-\beta_{2} \quad$ : Koefisien Regresi

$\mathrm{X}_{1} \quad$ :Persepsi

$\mathrm{X}_{2} \quad$ : Motivasi Diri

e :Standar error 


\section{HASIL DAN PEMBAHASAN}

Penelitian ini responden penelitian dibagi ke dalam beberapa karakteristik, yaitu berdasarkan jenis kelamin serta berdasarkan usia. Berikut merupakan data mengenai karakteristik responden penelitian yang termuat dalam Tabel 3.

Tabel 3.

Karakteristik Responden

\begin{tabular}{|c|c|c|c|}
\hline \multirow{2}{*}{ NO } & \multirow{2}{*}{ Karakteristik Responden } & \multicolumn{2}{|c|}{ Jumlah } \\
\hline & & Orang & Persentase (\%) \\
\hline \multirow[t]{4}{*}{1} & Jenis Kelamin & & \\
\hline & Wanita & 68 & $59 \%$ \\
\hline & Pria & 47 & $41 \%$ \\
\hline & Total & 115 & $100 \%$ \\
\hline \multirow[t]{4}{*}{2} & Usia & & \\
\hline & 21 & 56 & $49 \%$ \\
\hline & 20 & 59 & $51 \%$ \\
\hline & Total & 115 & $100 \%$ \\
\hline
\end{tabular}

Sumber : Data diolah, 2018

Jenis kelamin responden dapat digunakan sebagai suatu acuan ketegasan dan keterlibatan yang mempengaruhi emosi untuk mengambil suatu keputusan. Berdasarkan Tabel 3. dapat dilihat bahwa sebagian besar responden penelitian ini adalah wanita yaitu sebanyak 68 orang dan pria sebanyak 47 orang. Usia responden menggambarkan tingkat kedewasaan seseorang dalam melakukan suatu aktivitas yang akan mempengaruhi emosi untuk mengambil suatu keputusan. Berdasarkan Tabel 3. dapat dilihat bahwa yang menjadi responden dengan jumlah tertinggi yaitu pada usia 20 tahun sebanyak 59 orang dan pada usia 21 tahun sebanyak 56 orang.

Suatu instrumen yang valid ditunjukkan dengan r Pearson Correlation $\geq$ 0,30. Pada Tabel 4. menunjukkan bahwa seluruh variabel memiliki nilai koefisien 
korelasi dengan skor total seluruh item pernyataan lebih besar dari 0,30 . Hal ini menunjukkan butir-butir pernyataan dalam instrumen penelitian tersebut valid.

Tabel 4.

Hasil Uji Validitas

\begin{tabular}{cccc}
\hline Variabel & Indikator & Pearson Correlation & Keterangan \\
\hline \multirow{2}{*}{ Persepsi Mahasiswa } & X1.1 & 0,623 & Valid \\
(X1) & X1.2 & 0,707 & Valid \\
& X1.3 & 0,804 & Valid \\
& X1.5 & 0,655 & Valid \\
& X2.1 & 0,719 & Valid \\
& X2.2 & 0,488 & Valid \\
X2.3 & X2.4 & 0,634 & Valid \\
Motivasi Diri & X2.5 & 0,480 & Valid \\
(X2) & X2.6 & 0,521 & Valid \\
& X2.7 & 0,632 & Valid \\
& X2.8 & 0,706 & Valid \\
& X2.9 & 0,562 & Valid \\
& X2.10 & 0,700 & Valid \\
Kecerdasan Adversity & X3.1 & 0,729 & Valid \\
(X3) & X3.2 & 0,726 & Valid \\
& X3.3 & 0,380 & Valid \\
& X3.4 & 0,654 & Valid \\
& Y.1 & 0,774 & Valid \\
& Y.2 & 0,769 & Valid \\
& Y.3 & 0,511 & Valid \\
Minat Menjadi & Y.4 & 0,478 & Valid \\
Akuntan Publik & Y.5 & 0,656 & Valid \\
(Y) & Y.7 & 0,677 & Valid \\
& Y.8 & 0,574 & Valid \\
& Y.9 & 0,753 & Valid \\
& & 0,344 & Valid \\
\hline
\end{tabular}

Sumber : Data diolah, 2018

Hasil uji validitas instrumen penelitian yang disajikan pada tabel diatas menunjukkan bahwa semua instrument penelitian yang digunakan untuk mengukur variabel penelitian, yaitu: persepsi mahasiswa, motivasi diri, kecerdasan adversity, dan minat menjadi akuntan publik memiliki nilai koefisien korelasi di atas 0,30 sehingga seluruh indikator yang digunakan dinyatakan valid.

Uji reliabilitas dilakukan untuk menunjukkan sejauh mana suatu pengukuran kembali terhadap gejala yang sama. Suatu instrument dikatakan 
reliabel apabila instrument tersebut telah beberapa kali digunakan untuk mengukur objek yang sama dan menghasilkan data atau jawaban yang sama dari waktu ke waktu. Hasil uji reliabilitas dapat dilihat pada Tabel 5.

Tabel 5.

Hasil Uji Reliabilitas

\begin{tabular}{lcc}
\hline \multicolumn{1}{c}{ Variabel } & Cronbach's Alpha & Keterangan \\
\hline Persepsi Mahasiswa (X1) & 0,740 & Reliabel \\
Motivasi Diri (X2) & 0,793 & Reliabel \\
Kecerdasan Adversity (X3) & 0,718 & Reliabel \\
Minat Menjadi Akuntan Publik (Y) & 0,761 & Reliabel \\
\hline
\end{tabular}

Sumber: Data diolah, 2018

Suatu instrument dikatakan reliabel apabila instrument tersebut mempunyai nilai Alpha Cronbach lebih besar dari 0,70 (>0,70). Hasil uji reliabilitas yang ditampilkan dalam Tabel 5. menunjukkan bahwa setiap variabel memiliki nilai koefisien Alpha Cronbach lebih besar dari 0,70 (>0,70). Semua variabel dalam penelitian ini adalah reliabel dan pernyataan dalam kuesioner layak digunakan sebagai alat ukur.

Uji normalitas menggunakan uji Kolmogorov-Smirnov, dengan uji ini dapat diketahui data yang digunakan berdistribusi normal atau tidak. Apabila Sign $t$ hitung $>0.05$, maka data tersebut berdistribusi normal dan begitu juga sebaliknya (Santoso, 2001).

Tabel 6.

Hasil Uji Normalitas

\begin{tabular}{|c|c|c|}
\hline & & Unstandardized Residual \\
\hline $\mathrm{N}$ & & 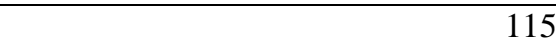 \\
\hline \multirow{3}{*}{ Normal Parameters ${ }^{\mathrm{a}, \mathrm{b}}$} & Mean & $0 \mathrm{E}-7$ \\
\hline & Std. Deviation & .91586221 \\
\hline & Absolute & .077 \\
\hline \multirow[t]{2}{*}{ Most Extreme Differences } & Positive & .049 \\
\hline & Negative & -.077 \\
\hline Kolmogorov-Smirnov Z & & .830 \\
\hline Asymp. Sig. (2-tailed) & & .497 \\
\hline
\end{tabular}


Berdasarkan hasil uji normalitas yang ditampilkan pada Tabel 6. diperoleh nilai signifikansi sebesar 0,497 dimana nilai signifikansi tersebut lebih besar dari 0,05, maka dapat disimpulkan bahwa data terdistribusi secara normal.

Uji multikolinieritas digunakan untuk mengetahui apakah antara variabel bebas terjadi multikolinieritas atau tidak. Uji yang digunakan yaitu dengan melihat nilai VIF (Varian Inflation Factor) dan Tolerance pada proses regresi biasa, jika keduanya mendekati 1 atau besaran VIF kurang dari 10 maka model tidak terkena multikolinieritas. Berdasasrkan hasil pengujian multikolinearitas dapat diperoleh hasil sebagai berikut.

Tabel 7.

Hasil Uji Multikolinearitas

\begin{tabular}{ccc}
\hline Model & Tolerance & Colinearity Statistic \\
& 0,434 & VIF \\
\hline X1 & 0,280 & 2,305 \\
X3 & 0,491 & 3,571 \\
X3 & & 2,037 \\
\hline
\end{tabular}

Sumber: Data diolah, 2018

Hasil pengujian pada Tabel 7. menunjukkan bahwa nilai tolerance pada masing-masing variabel lebih besar dari $10 \%(0,1)$, demikian pula dengan nilai VIF masing-masing variabel yang lebih kecil dari 10. Dengan demikian dapat disimpulkan antara variabel bebas dalam penelitian ini tidak terjadi multikolinearitas.

Uji Heterokedastisitas dilakukan untuk menguji apakah dalam model regresi terjadi ketidaksamaan varian dari residu satu pengamatan ke pengamatan lain. Model regresi yang baik adalah model homokedastisitas atau tidak terjadi heterokedastisitas. Apabila model suatu regresi mengandung gejala heterokedastisitas, maka hasil yang diberikan akan menyimpang. Untuk 
mengetahui apakah sebuah regresi memiliki indikasi heterokedastisitas, maka masalah tersebut bisa dideteksi dengan menggunakan uji Glejser Test. Jika probabilitas signifikansinya di atas 0,05 maka dapat dikatakan bahwa pada model regresi tidak mengandung masalah heterokedastisitas . Hasil uji heterokedastisitas dapat dilihat pada Tabel 8 .

Tabel 8.

Hasil Uji Heteroskedastisitas

\begin{tabular}{ccc}
\hline Model & Sig. & Keterangan \\
\hline X1 & 0,098 & Lolos Uji \\
X2 & 0,112 & Lolos Uji \\
X3 & 0,828 & Lolos Uji \\
\hline
\end{tabular}

Sumber: Data diolah, 2018

Tabel 8. menunjukkan bahwa seluruh variabel memiliki nilai signifikan lebih besar dari 0,05 sehingga model regresi pada penelitian ini tidak mengandung gejala heteroskedastisitas.

Analisis regresi linier berganda digunakan untuk menguji pengaruh variabel motivasi karir, motivasi kualitas, motivasi sosial, dan biaya pendidikan terhadap minat mahasiswa akuntansi mengikuti pendidikan profesi akuntansi. Hasil analisis regresi linier berganda dapat dilihat pada tabel 9.

Tabel 9.

Hasil Uji Analisis Regresi Linier Berganda

\begin{tabular}{|c|c|c|c|c|c|}
\hline \multirow[t]{2}{*}{ Model } & \multicolumn{2}{|c|}{$\begin{array}{l}\text { Unstandardized } \\
\text { Coefficients }\end{array}$} & $\begin{array}{l}\text { Standardized } \\
\text { Coefficients }\end{array}$ & $\mathbf{t}$ & Sig. \\
\hline & B & Std. Error & Beta & & \\
\hline (Constant) & 17,470 & 1,010 & & 17,294 & 0,000 \\
\hline $\mathrm{X} 1$ & 0,409 & 0,064 & 0,478 & 6,430 & 0,000 \\
\hline $\mathrm{X} 2$ & 0,175 & 0,050 & 0,325 & 3,512 & 0,001 \\
\hline $\mathrm{X} 3$ & 0,199 & 0,090 & 0,155 & 2,220 & 0,028 \\
\hline $\mathrm{R}$ & 0,857 & & & & \\
\hline $\mathrm{R}^{2}$ & 0,734 & & & & \\
\hline Adjusted $\mathrm{R}^{2}$ & 0,727 & & & & \\
\hline
\end{tabular}

Berdasarkan perhitungan analisis regresi linear berganda, maka didapatkan hasil persamaan regresi sebagai berikut: 
Putu Vicky Yuliana Paramita S dan Maria Madiatrix Ratna Sari. Pengaruh...

$\mathrm{Y}=17,470+0,409 \mathrm{X}_{1}+0,175 \mathrm{X}_{2}+0,199 \mathrm{X}_{3}+\mathrm{e}$

Berdasarkan persamaan tersebut, maka pengaruh persepsi mahasiswa, motivasi diri, kecerdasan adversity pada minat menjadi akuntan publik dapat diartikan yaitu diketahui konstanta besarnya 17,470 mengandung arti jika persepsi mahasiswa $\left(\mathrm{X}_{1}\right)$, motivasi diri $\left(\mathrm{X}_{2}\right)$, dan kecerdasan adversity $\left(\mathrm{X}_{3}\right)$ dianggap konstan pada angka 0 , maka nilai pada minat menjadi akuntan publik (Y) adalah sebesar 17,470. Nilai koefisien $\beta_{1}$ sebesar 0,409 mempunyai arti bahwa jika variabel persepsi mahasiswa $\left(\mathrm{X}_{1}\right)$ meningkat, maka akan menyebabkan peningkatan pada minat menjadi akuntan publik (Y), dengan asumsi variabel bebas lainnya dianggap konstan. Nilai koefisien $\beta_{2}$ sebesar 0,175 mempunyai arti bahwa jika variabel motivasi diri $\left(\mathrm{X}_{2}\right)$ meningkat, maka akan menyebabkan peningkatan pada minat menjadi akuntan publik (Y), dengan asumsi variabel bebas lainnya dianggap konstan. Nilai koefisien $\beta_{3}$ sebesar 0,199 mempunyai arti bahwa jika variabel kecerdasan adversity $\left(\mathrm{X}_{3}\right)$ meningkat, maka akan menyebabkan peningkatan pada minat menjadi akuntan publik (Y), dengan asumsi variabel bebas lainnya dianggap konstan.

Berdasarkan Tabel 9. menunjukkan bahwa koefisien determinasi yaitu nilai adjusted $R^{2}$ adalah 0,727 . Hasil tersebut memiliki arti bahwa pengaruh variabel persepsi mahasiswa, motivasi diri, serta kecerdasan adversity pada minat menjadi akuntan publik adalah sebesar $72,7 \%$, sedangkan sisanya yaitu sebesar $27,3 \%$ dipengaruhi oleh variabel lain di luar model penelitian.

Uji kelayakan model bertujuan untuk mengetahui kelayakan model regresi linier berganda sebagai alat analisis yang menguji variabel bebas memiliki 
pengaruh terhadap variabel terikat. Model dalam penelitian dikatakan layak apabila nilai probabilitas signifikansinya $<0,05$. Hasil uji kelayakan model (uji F) dapat dilihat pada Tabel 10 .

Tabel 10.

Hasil Uji Kelayakan Model (Uji F)

\begin{tabular}{cccccc}
\hline Model & Sum of Squares & df & Mean Square & F & Sig. \\
\hline Regression & 263,559 & 3 & 87,853 & 101,980 & 0,000 \\
Residual & 95,624 & 111 & 0,861 & & \\
Total & 359,183 & 114 & & & \\
\hline
\end{tabular}
Sumber: Data diolah, 2018

Berdasarkan Tabel 10. hasil uji F menunjukkan bahwa nilai F hitung sebesar 101,980 dengan nilai signifikansi 0,000. Dapat disimpulkan bahwa terdapat pengaruh yang signifikan antara persepsi mahasiswa, motivasi diri, dan kecerdasan adversity pada minat mahasiswa akuntansi menjadi akuntan publik. Sehingga model penelitian dikatakan layak digunakan sebagai model regresi.

Uji t dalam penelitian ini bertujuan untuk menguji apakah masing-masing variabel bebas $(\mathrm{X})$ yang digunakan dalam model regresi memiliki pengaruh signifikan terhadap variabel terikat $(\mathrm{Y})$. Apabila nilai signifikansinya $>0,05$ maka hipotesis ditolak (koefisien regresi tidak signifikan), dan apabila nilai signifikansi $\leq$ 0,05 maka hipotesis diterima (koefisien regresi signifikan). Hasil uji hipotesis (uji T) dapat dilihat pada Tabel 11.

Tabel 11.

Hasil Uji Hipotesis (Uji t)

\begin{tabular}{llll}
\hline Variabel & thitung $_{\text {nasil }}$ & sig. & Hasil Hipotesis \\
\hline Persepsi Mahasiswa & 6,430 & 0,000 & $\mathrm{H}_{1}$ Diterima \\
Motivasi Diri & 3,512 & 0,001 & $\mathrm{H}_{2}$ Diterima \\
Kecerdasan Adversity & 2,220 & 0,028 & $\mathrm{H}_{3}$ Diterima \\
\hline Sumber : Data diolah, 2018 & &
\end{tabular}

Berdasarkan Tabel 11. maka hasil pengujian secara parsial masing-masing variabel independen terhadap dependen dapat dijabarkan sebagai berikut. 
Pengujian pada hipotesis pertama menunjukkan bahwa variabel persepsi mahasiswa berpengaruh positif terhadap minat mahasiswa akuntansi non reguler menjadi akuntan publik. Signifikansi pengaruh persepsi mahasiswa pada minat mahasiswa akuntansi menjadi akuntan publik dapat diketahui dengan membandingkan nilai $t_{\text {sig }}$ dengan $\alpha(0,05)$. Diketahui bahwa nilai thitung persepsi mahasiswa $\left(\mathrm{X}_{1}\right)$ sebesar 6,430 dengan signifikansi sebesar 0,000. Nilai signifikansi sebesar $0,000<0,05$ maka hipotesis diterima. Hasil tersebut memiliki arti bahwa semakin tinggi persepsi mahasiswa mengenai profesi akuntan publik maka semakin tinggi minat mahasiswa akuntansi menjadi akuntan publik. Dengan demikian, $\mathrm{H}_{1}$ diterima.

Robbins dan Judge (2009:173) mendefinisikan persepsi sebagai suatu proses yang ditempuh individu untuk mengorganisasikan dan menfsirkan kesan -kesan indera mereka agar memberi makna bagi lingkungan mereka. Persepsi seseorang tidak timbul begitu saja, tetapi ada berbagai macam faktor yang mempengaruhinya. Faktor itulah yang menyebabkan mengapa dua orang yang melihat sesuatu mungkin memberi interpretasi yang berbeda tentang yang dilihatnya tersebut. Teori motivasi yang diungkapkan oleh Robbins (2011) menyatakan bahwa sikap seseorang terbentuk dari tiga komponen salah satunya cognitive component yaitu merupakan keyakinan dari informasi yang dimiliki oleh seseorang yang akan mempengaruhi minat seseorang terhadap terhadap profesi yang akan dijalani. Apabila seseorang mempunyai persepsi yang positif akan sesuatu hal, maka cenderung akan mendukung hal tersebut . Begitu pula sebaliknya apabila seseorang mempunyai persepsi yang negatif akan sesuatu hal 
maka cenderung untuk menghindari hal tersebut. Setiap individu dalam mempersepsikan mengenai profesi akuntan publik bermacam-macam. Ada yang mempersepsikan mengenai akuntan publik itu positif maupun negatif sehingga secara tidak langsung dapat mempengaruhi keinginannya untuk berprofesi sebagai akuntan publik.

Pada penelitian sebelumnya yang dilakukan oleh Diana (2015) menyatakan bahwa persepsi berpengaruh terhadap pemilihan karir sebagai akuntan publik oleh mahasiswa akuntansi. Dimana mahasiswa selama belajar di perguruan tinggi menerima informasi yang berhubungan dengan akuntan baik secara formal maupun informal. Informasi tersebut dapat memberikan persepsi yang berbeda dari kenyataan yang obyektif. Cara individu dalam pengambilan dan kualitas dari pilihan terakhir mereka sebagian besar dipengaruhi oleh persepsi mereka (Robbis dan Judge, 2009:173). Dalam hal ini, Mahasiswa akuntansi akan memilih profesi tertentu karena dia mempunyai persepsi yang baik terhafap profesi tersebut.

Pengujian pada hipotesis kedua menunjukkan bahwa variabel motivasi diri berpengaruh positif terhadap minat menjadi akuntan publik pada mahasiswa akuntansi non reguler . Signifikansi pengaruh motivasi diri pada minat mahasiswa akuntansi menjadi akuntan publik dapat diketahui dengan membandingkan nilai $t_{\text {sig }}$ dengan $\alpha(0,05)$. Diketahui bahwa nilai $t_{\text {hitung }}$ motivasi diri $\left(\mathrm{X}_{2}\right)$ sebesar 3,512 dengan signifikansi sebesar 0,001. Nilai signifikansi sebesar 0,001 $<0,05$ maka hipotesis diterima. Hasil tersebut memiliki arti bahwa semakin tinggi motivasi diri mahasiswa maka semakin tinggi minat mahasiswa akuntansi menjadi akuntan publik. Dengan demikian, $\mathrm{H}_{2}$ diterima. 
Menurut Sardiman (2005), motivasi diri adalah suatu motif-motif (daya penggerak) yang menjadi aktif dan berfungsinya tidak perlu dirangsang dari luar karena dari diri individu sudah terdapat dorongan untuk melakukan sesuatu. Motivasi diri juga juga dapat disebut motivasi internal. Dalam kehidupan seharihari motivasi diri dibutuhkan karena dapat menyemangati diri seseorang untuk mencapai apa yang diinginkannya. Seseorang yang mempunyai motivasi diri yang kuat akan sesuatu hal pasti cenderung akan berusaha semaksimal mungkin untuk mendapatkan hal tersebut. Sehingga ia akan melakukan apapun untuk mencapai hal yang diinginkannya. Motivasi diri dapat digambarkan dengan kemauan untuk maju, kemampuan dalam mengambil inisiatif dan bersikap efektif, serta kemampuan dalam menghadapi kegagalan. Mahasiswa akuntansi yang memiliki motivasi diri yang kuat untuk menjadi akuntan publik, pasti akan selalu berusaha sebaik mungkin agar dapat mencapai keinginannya tersebut.

Motivasi diri dapat digambarkan dengan suatu kemauan untuk maju, bertindak efektif, serta kemampuan dalam menghadapi suatu kegagalan yang dialami. Mahasiswa akuntansi yang mempunyai motivasi yang kuat untuk menjadi akuntan publik pasti akan selalu berusaha sebaik mungkin agar dapat mencapai keinginannya tersebut.

Penelitian sebelumnya yang dilakukan Arifianto (2014) menyatakan bahwa motivasi diri berpengaruh positif terhadap minat menjadi akuntan publik pada mahasiswa prodi akuntansi fakultas ekonomi universitas negeri yogyakarta. Pengujian pada hipotesis ketiga menunjukkan bahwa variabel kecerdasan adversity berpengaruh positif terhadap minat mahasiswa akuntansi non reguler 
menjadi akuntan publik. Signifikansi pengaruh kecerdasan adversity pada minat mahasiswa akuntansi menjadi akuntan publik dapat diketahui dengan membandingkan nilai $t_{\text {sig }}$ dengan $\alpha(0,05)$. Diketahui bahwa nilai $t_{\text {hitung }}$ kecerdasan adversity $\left(\mathrm{X}_{3}\right)$ sebesar 2,220 dengan signifikansi sebesar 0,028. Nilai signifikansi sebesar 0,028 $<0,05$ maka hipotesis diterima. Hasil tersebut memiliki arti bahwa semakin tinggi kecerdasan adversity mahasiswa maka semakin tinggi minat mahasiswa akuntansi menjadi akuntan publik. Dengan demikian, $\mathrm{H}_{3}$ diterima.

Kecerdasan Adversity juga mempengaruhi minat mahasiswa untuk menjadi akuntan publik. (Adversity Intelligence) adalah suatu konsep mengenai kualitas pribadi yang dimiliki seseorang untuk menghadapi berbagai kesulitan dan dalam usaha mencapai kesuksesan di berbagai bidang dalam hidupnya (Paul G Stolz, 2000: 9). Adversity Intelligence menginformasikan pada individu mengenai kemampuannya dalam menghadapi sebuah keadaan atau situasi yang sulit dan kemampuan untuk mengatasinya, meramalkan individu yang mampu dan tidak mampu menghadapi kesulitan, meramalkan mereka yang akan melampaui dan mereka yang akan gagal melampauin harapan-harapan atas kinerja dan potensi yang dimiliki, dan meramalkan individu yang akan menyerah dan yang akan bertahan dalam menghadapi kesulitan. dengan kata lain, kecerdasan adversity mempengaruhi minat mahasiswa secara positif. Mahasiswa yang memiliki kecerdasan adversity yang tinggi, maka ia akan memiliki semangat yang tinggi serta mampu menghadapi setiap kesulitan dan tantangan yang muncul dalam persyaratan untuk menjadi seorang akuntan publik. 


\section{SIMPULAN}

Berdasarkan pembahasan hasil penelitian di atas, dapat disimpulkan bahwa persepsi mahasiswa, motivasi diri, dan kecerdasan adversity berpengaruh positif pada minat mahasiswa akuntansi non reguler Universitas Udayana menjadi akuntan publik. Sedangkan saran yang dapat diberikan adalah bagi peneliti selanjutnya disarankan agar memperluas ruang lingkup responden penelitian, tidak hanya pada mahasiswa akuntansi di Universitas Udayana, tetapi dapat menambahkan responden dari mahasiswa akuntansi atau non akuntansi di luar Universitas Udayana. Selain itu juga agar menambah variabel-variabel lain yang dapat memengaruhi minat mahasiswa untuk menjadi akuntan publik, seperti variabel pertimbangan pasar kerja, pengakuan profesional, motivasi mencari ilmu, serta penghargaan finansial.

\section{REFERENSI}

Adams, S. J., Pryor, L. J. \&Adams, S. L. (1994). Attraction and retention of highaptitude students in accounting: an exploratory longitudinal study, Issues in Accounting Education, 9(1), 45-48

Andersen, W. (2012). Analisis Persepsi Mahasiswa Akuntansi Dalam Memilih Profesi Sebagai Akuntan. Skripsi. Universitas Diponegoro.

Arifianto \& Sukanti. (2014). Pengaruh Motivasi Diri Dan Persepsi Mengenai Profesi Akuntan Publik Terhadap Minat Menjadi Akuntan Publik Pada Mahasiswa Prodi Akuntansi Fakultas Ekonomi Universitas Negeri Yogyakarta. Jurnal Nominal, 3(2), 151-153.

Ayuningtyas, H. Y. (2012). Pengaruh Pengalaman Kerja, Independensi, Objektifitas, Integritas, dan Kompetensi Terhadap Kualitas Hasil Audit (Studi Kasus Pada Auditor Inspekorat Kota/Kabupaten di Jawa Tengah). Skripsi. Universitas Diponegoro Semarang.

Boynton, W. C., Johnson., Raymond, N., and Kell, W. G. (2001). Modern Auditing. Edisi Ketujuh. Jilid 2. Jakarta: Erlangga. 
Carpenter, C. G \& Strawser, R. H. (1970). Job Preferences Selection of Accounting Students. Journal of Accountancy, 84-86

Dewi, I. A. R. P. (2018). Persepsi Mahasiswa Akuntansi Reguler Dan Non Reguler Universitas Udayana Terhadap Minat Mengikuti Pendidikan Profesi Akuntansi (PPAk). Skripsi. Universitas Udayana.

Djaali. (2007). Psikologi Pendidikan. Jakarta: Bumi Aksara.

Felton, S. (1994). Factors influencing the bussines student's choice of a career in chartered accountancy. Issues in Accounting Education, 9(1), 131-141.

Fitria. (2016). Persepsi dan Minat Mahasiswa Jurusan Akuntansi Fakultas Ekonomi Terhadap Profesi Akuntan Publik. Naskah Publikasi. Universitas Muhammadiyah Surakarta.

Gibson, J., John, M. I., and James, H. D. J. (1997). Organization Behaviour Structure Process. Ninth Edition. Mc Graw-hill, Inc.

Ghozali, I. (2013). Aplikasi Analisis Multivariate Dengan Program SPSS. Semarang: Badan Penerbit Universitas Diponegoro.

Hadiprasetyo, T. dan Endra, M. S. (2014). Pengaruh Motivasi, Persepsi Biaya Pendidikan dan Persepsi Masa Studi pada Minat mengikuti PPAk. Jurnal PROFITA, 2(7), 1-14.

IAI. (2015). Peluang dan Tantangan Akuntan di Era MEA. http://www.iaiglobal.or.id/v03/files/file_publikasi/6.\%2017\%20Sept_Pan el\%20Session_Prof.\%20Ilya\%20Avianti.pdf. Diunduh tanggal 7, bulan Desember. Tahun 2017.

Kreitner, R. \& Kinicki, A. (2001). Organizational Behavior. Fifth Ed. Irwin McGraw-Hill. Boston.

Lang, J. (1987). Creating Architectural Theory, The Role of The Behavioral Sciences in Environmental Design. Van Nostrand Reinhold Company Inc. New York.

Lestari, I. G. A. K. dan Yadnyana, I. K. (2013). Persepsi dan Minat Mahasiswa Jurusan Akuntansi Fakultas Ekonomi Universitas Udayana Terhadap Profesi Akuntan Publik. E-Jurnal Akuntansi, 3(1), 195-211.

Lubis, A. I. (2014). Akuntansi Keprilakuan. Jakarta:Salemba Empat. 
Merdekawati, D. P. dan Ardiani, I. S. (2011). Faktor-faktor yang Mempengaruhi Pemilihan Karir Akuntan Publik dan Non Akuntan Publik. Jurnal Aset, 13(1), 9-19.

Mulyadi. (2011). Auditing Buku 1. Jakarta: Salemba Empat.

Naukoko, P. A. (2017). Profesi Akuntan Di Era Masyarakat Ekonomi Asean (MEA). Journal of ASEAN Studies on Maritime Issues, 3(4), 42-51.

Rachman, N. A. (2012). Pengaruh Motivasi Terhadap Minat Mahasiswa Akuntansi Untuk Memilih Profesi Sebagai Akuntan Publik (Studi Empiris Pada Universitas Hasanuddin Makassar). Naskah Publikasi. Universitas Hasanuddin.

Ratnantari, I. G. A. M \& Asri, D. P. (2017). Pengaruh Kecerdasan Intelektual, Kecerdasan Emosional, Kecerdasan Spiritual, Independensi dan Komitmen Organisasi Pada Kinerja Auditor. E-Jurnal Akuntansi, 20(1), 814-844.

Robbins, S. P. \& Judge, T. A. (2015). Perilaku Organisasi. Jakarta: Salemba.

Sardiman. (2005). Interaksi dan Motivasi Belajar Mengajar. Jakarta: Raja Grafndo Persada.

Srimulyani, V. A. (2013). Analisis Pengaruh Kecerdasan Adversitas, Internal Locus Of Control, Kematangan Karir Terhadap Intensi Berwirausaha Pada Mahasiswa Bekerja. Skripsi. Universitas Katolik Widya Mandala Madiun.

Stoltz, P. G. (1997). Adversity Quotient: turning obstacles into opportunities. Canada: John Wiley \& Sons.

Stoltz, P. G. (2007). Adversity Quotient: Mengubah hambatan menjadi peluang. (7th ed.). Jakarta: PT Grasindo.

Stoltz, P. G. \& Weihenmayer. (2010). The Adversity Advantage: Turning Everyday Struggles Into Everyday Greatness. (2 $2^{\text {nd }}$ ed.). New York: Fireside.

Sugiyono. (2017). Metode Penelitian Kuantitatif, Kualitatif, dan R\&D. Bandung: Alfabeta.

Wade, C. \& Carol, T. (2007). Psikologi. Jakarta: Erlangga. 
Warsitasari, I. A. T. S. (2017). Pengaruh Motivasi, Persepsi, Penghargaan Finansial, Pertimbangan Pasar Kerja dan Pengakuan Profesional Pada Pemilihan Karir Sebagai Akuntan Publik. E-Jurnal Akuntansi, 21(3), 2222-2252.

Winardi. (2002). Motivasi dan Pemotivasian dalam Manajemen. Jakarta: Raja Grafindo Persada

Witherington. (1999). Practical Aspect of Authentic Assesment: Putting The Pieces Together. Washington: MCGraw-Hill. 